\title{
Eutanasie as vrywillige keuse deur persone met demensie, met verwysing na die praktyk in Nederland - 'n voorlopige teologies-etiese beoordeling
}

\author{
Author: \\ Adriaan L. Rheeder ${ }^{1}$ \\ Affiliation: \\ ${ }^{1}$ School for Ecclesiastical \\ Studies, Potchefstroom \\ Campus, North-West \\ University, South Africa \\ Correspondence to: \\ Riaan Rheeder \\ Email: \\ riaan.rheeder@nwu.ac.za \\ Postal address: \\ PO Box 62, Potchefstroom \\ 2520, South Africa \\ Dates: \\ Received: 12 Jan. 2012 \\ Accepted: 15 Apr. 2012 \\ Published: 04 Oct. 2012 \\ How to cite this article: \\ Rheeder, R., 2012, 'Eutanasie \\ as vrywillige keuse deur \\ persone met demensie, met \\ verwysing na die praktyk in \\ Nederland - ' $n$ voorlopige \\ teologies-etiese beoordeling', \\ In die Skriflig/In Luce Verbi \\ 46(1), Art. \#49, 12 pages. \\ http://dx.doi.org/10.4102/ \\ ids.v46i1.49
}

Vanaf die 1970s blyk dit dat eutanasie op aanvraag in Nederland toegepas word. In 2002 word die praktyk van eutanasie op versoek gewettig. Wanneer daar aan sekere sorgvuldigheidsvereistes voldoen word, word eutanasie as wettig beskou. Eutanasie op versoek word die meeste op terminale kankerpasiënte uitgevoer. Vanaf 2004 is die neiging om eutanasie op versoek van pasiënte met vroeë demensie uit te voer. Verskeie persone het ook'n lewende testament opgestel waarin eutanasie versoek word indien demensie sou ontwikkel. Die doel van hierdie artikel is 'n voorlopige beoordeling van hierdie praktyk in die lig van die gereformeerde etiek. Uit die studie wil dit voorkom asof die praktyk van eutanasie aan pasiënte met demensie in die algemeen nie aanvaarbaar is nie. Hierdie artikel beredeneer voorlopig dat die Skrif nie vreemd staan teenoor die moontlikheid van ' $n$ uitsondering onder bepaalde omstandighede nie.

Life to the bitter end: Euthanasia as voluntary choice by persons with dementia, with reference to the practice in the Netherlands - a preliminary theological-ethical evaluation. Euthanasia on request has been applied since the 1970s in the Netherlands. In 2002, the practice of euthanasia on request was legalised. When there is certainty that 'rules of due care' are satisfied, euthanasia is regarded as legal. Most euthanasia on request is executed on terminal cancer patients. From about 2004 the trend is found that euthanasia on request is performed to patients with early dementia. Several persons also have a living will in which euthanasia is requested if dementia develops. The purpose of this article is to preliminary judge this practice in the light of the reformed ethics. From this study it would appear that the practice of euthanasia to patients with dementia in general are not acceptable. This article argues provisionally that Scripture is not strange to the possibility of an exception under certain circumstances.

'Suicide can be motivated by the desire to live only if one can stand alone, or by the desire to die because one fears standing alone.' (The American President's Council on Bioethics)

\section{Inleiding}

Volgens Vilela en Caramelli (2009:266) word eutanasie vir persone met demensie as vraagstuk 'n toenemende belangrike tema in die moderne bioetiek. Uit die gegewens wat volg blyk dit dat die bioetiese werklikheid van eutanasie aan persone met demensie ' $n$ besonder aktuele vraagstuk is.

\section{Die moraal van eutanasie aan pasiënte met demensie Eutanasie vir pasiënte met demensie - 'n aktuele vraagstuk}

Onlangs het Barones Mary Helen Warnock, een van Brittanje se mees gerespekteerde bioetici, groot polemiek veroorsaak met haar standpunt dat persone met demensie vrywillige eutanasie (geassisteerde selfdoding) ernstig moet oorweeg. 'If you're demented, you're wasting people's lives - your family's lives - and you're wasting the resources of the National Health Service' (White 2008). Die vorige Nederlandse minister van gesondheid, Els Borst-Eilers (1994-2002), het verklaar dat sy 'n sterk ondersteuner van die wettiging van eutanasie vir persone met demensie is (Hertogh et al. 2007a:49).

Eutanasie vir persone met demensie word weer tans wêreldwyd gedebatteer en deur verskeie Wes-Europese lande gesien as 'n vorm van 'versorging' van mense aan die einde van hulle lewens. Rietjens et al. (2009:271, 279) het tot hierdie gevolgtrekking gekom na 'n intensiewe studie van aktiewe en passiewe eutanasie in Nederland, België, Denemarke, Italië, Swede en Switserland.

In 'n resente studie deur Brasiliaanse navorsers onder geneeshere wat pasiënte met demensie behandel, het $66.6 \%$ aangedui dat hulle ook ten gunste van eutanasie vir sodanige pasiënte 
is (Vilela \& Caramelli 2009:266). 'n Onlangse studie oor eutanasie in Nederland het aangetoon dat $44.0 \%$ van die geneeshere wat in die studie betrek is, aangedui het dat hulle in beginsel geen probleem daarmee ondervind om eutanasie in pasiënte met demensie (met 'n lewende testament) uit te voer nie en hulle sal dit waarskynlik in die toekoms doen (Rurup et al. 2006b:1552-1563; Gastmans \& De Lepeleire 2009:3-4).

Dieselfde studie in Brasilië het getoon dat $22.0 \%$ van die familielede wat aan die studie deelgeneem het, aangedui het dat hulle eutanasie vir hulle familie met demensie sal oorweeg (Vilela \& Caramelli 2009:265-267). 'n Studie deur Rurup et al. (2006a:372-380) in Nederland het ook aangetoon dat die familie van pasiënte met demensie oor die algemeen meer ten gunste is van eutanasie in vergelyking met byvoorbeeld geneeshere en verpleegpersoneel. Negentig persent van die familie, $57.0 \%$ van die verpleegpersoneel en $16.0 \%$ van die geneeshere het aangedui dat eutanasie vir persone met demensie (met 'n lewende testament) aanvaarbaar is. Dieselfde tendens is ook in 'n soortgelyke studie in Finland aangedui (vgl. ook Gastmans \& De Lepeleire 2009:4).

Genadedood word tans in Nederland vir persone met demensie, selfs binne ouetehuise met 'n sterk gereformeerde grondslag, nie verbied nie en daar word aan (gereformeerde) bejaardes die geleentheid gebied om genadedood as opsie te oorweeg en uit te voer (Regionale Toetsingscommissies Euthanasie 2008:13).

Verskeie wetenskaplikes vestig die aandag daarop dat die wêreldbevolking drasties ouer word en in die toekoms sal toeneem (vgl. ook Hertogh et al. 2007a:49; Gastmans \& De Lepeleire 2009:2). Dieselfde tendens geld ook vir die ontwikkelende lande, soos byvoorbeeld Brasilië (Vilela \& Caramelli 2009:263) en Suid-Afrika (Joubert \& Bradshaw 2005:204-216). Volgens Hertogh et al. (2007a:49) is die feit dat die wêreldbevolking ouer word en demensie sterk verband hou met ouderdom die hoofrede waarom eutanasie by persone met demensie ' $n$ oorheersende tema in die bioetiek geword het. Een persent van alle persone bo 50 jaar ontwikkel demensie, $2.5 \%$ bo 70 jaar, $5.0 \%$ bo 75 jaar, $12.0 \%$ bo 80 jaar, $20.0 \%$ - 30.0\% bo 85 jaar en $40.0 \%$ - 50.0\% bo 90 jaar (Feinberg \& Feinberg 1993:100, 419). 'n Steeds ouerwordende wêreldbevolking sal 'n verdere toename van demensie tot gevolg hê (Gastmans \& De Lepeleire 2009:2).

In Nederland kom eutanasie aan pasiënte met vroeë en gevorderde demensie reeds voor (kyk 'Eutanasie vir pasiënte met gevorderde demensie' en 'Eutanasie vir pasiënte met vroeë demensie'), terwyl die algemene publiek se ondersteuning van eutanasie aan sulke pasiënte al sterker word (Hertogh et al. 2007a:54). Hierdie verlange na eutanasie is vanselfsprekend nie net tot Nederland beperk nie. In 1990 het Dr Jack Kevorkian in Amerika 'n 54-jarige vrou met demensie met selfdoding gehelp (Feinberg \& Feinberg 1993:99).

In 'n sekere sin hang die vraag na eutanasie by pasiënte met demensie nóú saam met 'n soortgelyke vraag wat tans druk in Nederland bespreek word, naamlik die beskikbaarstelling van 'n selfdodingpil (bekend as pil van Drion of laastewil-pil) as 'n farmaseutiese kontrole-instrument spesifiek vir bejaarde persone wat lewensmoeg geword het (Hertogh et al. 2007b:5). Kernbegrippe in die debat is eensaamheid, onafhanklikheid, verveeldheid, 'n gebrek aan vitaliteit en sosiale relevansie (Boer 2002). Volgens Sorgdrager (2008) sal dokters nie maklik so 'n tipe versoek tot eutanasie oorweeg nie, maar dit het al plaasgevind.

Die aksent en doel van die etiese beoordeling word gedoen vanuit die perspektief van die Christengelowige wat moontlik in die toekoms met die problematiek van eutanasie aan familie met demensie gekonfronteer mag word (Vandrunen 2009:197, 205). Dit is bekend dat eutanasie in Nederland gelegaliseer is. Hierdie etiese beoordeling sal nie die Nederlandse wet op eutanasie en praktyk per se eties beoordeel nie, hoewel die beoordeling sekere implikasies vir die betrokke wet en praktyk het. Die wet en praktyk word as 'n gegewe realiteit aanvaar en die etiese beoordeling word vanuit 'n gerereformeede teologiese perspektief gedoen. Laasgenoemde perspektief sluit ook die gebruik van teologiese bronne en idees van buite die gereformeerde teologiese tradisie in, asook die gebruik van sekulêre bioetiese bronne en gedagtes (Jer 29:4-9; Vandrunen 2009:16, 23-37). Myns insiens is Andersen en Hallamaa (1995) korrek wanneer hulle in verband met eutanasie aanvoer:

We must always remain ethically alert, not pretending to have found a final answer to our questions and not condemning people who have arrived at a moral conclusion we ourselves do not accept.(p. 67; vgl. ook Dementia 2002:107)

Hierdie artikel wil help dink, voorlopig beoordeel en beantwoord.

\section{Eutanasie in Nederland - sorgvuldigheid maak dit wettig}

Eutanasie op versoek word reeds vanaf 1973 sporadies in Nederland uitgevoer. In 1993 is die eutanasiebeleid deur middel van ' $n$ bepaling in die wet op lykbesorging gereël (Boer 2009b). Op 01 April 2002 het die Nederlandse wet op vrywillige eutanasie in werking getree (Hertogh et al. 2007a:48; Nederland 2009a:4). Die feit dat daar sprake was van 'n selfstandige wet vir eutanasie, en dit nie meer bloot as ' $n$ aanhangsel by ' $n$ ander wet hanteer is nie, is ' $n$ aanduiding dat eutanasie ' $n$ aanvaarbare praktyk in Nederland geword het (Boer 2009b). In 1998 was ongeveer 90.0\% van die Nederlandse bevolking ten gunste van eutanasie. Wat hierdie wet merkwaardig maak, is dat dit in 'n land met sterk Christelike tradisies voorkom (Rietjens et al. 2009:272-273). ${ }^{1}$

In hierdie artikel word die term eutanasie gebruik wat ook geassisteerde selfdoding insluit (vgl. Rietjens et al. 2009:271; Vandrunen 2009:205). Eersgenoemde gebruik van die term dui op die geneesheer wat 'n pasiënt 'n dodelike middel inspuit, terwyl die tweede gebruik daarvan daarop dui dat die geneesheer 'n middel aan die pasiënt verskaf wat 1.Eutanasie en geassisteerde selfdoding word tans in België, Switserland en in die Amerikaanse State van Oregon en Washington toegelaat (Rietjens et al. 2009:281). 
hy of sy self kan inneem (Regionale Toetsingscommissies Euthanasie 2009:29; Gastmans \& De Lepeleire 2009:1). Binne die Nederlandse regstelsel word tussen 'n negatiewe en positiewe lewende testament onderskei. 'n Negatiewe lewende testament stipuleer watter tipe behandeling in bepaalde omstandighede nie gebruik mag word nie. 'n Pasiënt kan byvoorbeeld stipuleer dat buisvoeding weerhou word (Dementia 2002:100). Hierdie versoek is afdwingbaar (Rurup et al. 2005:1143). Binne die Nederlandse wetgewing het die pasiënt dus die reg op passiewe eutanasie. Die etiese studie van hierdie artikel sluit nie die beoordeling van passiewe eutanasie by pasiënte met demensie in nie. ${ }^{2}$

'n Positiewe lewende testament bepaal watter tipe mediese behandeling of ander aksies (soos eutanasie) in bepaalde omstandighede gebruik moet word (Dementia 2002:100). Die Nederlandse Wet op Lewensbeëindiging (art. 2.2) maak voorsiening dat 'n toerekeningsvatbare persoon 'n lewende testament mag opstel waarin hy aan 'n dokter opdrag gee om, ten tye van ontoerekenbaarheid weens demensie, eutanasie op hom of haar toe te pas (Rurup et al. 2005:1138; Nederland 2009b). ${ }^{3}$ Hierdie lewende testament staan ook bekend as advanced directives. So 'n skriftelike instruksie word as 'n geïnformeerde toestemming (informed consent) beskou. Die lewende testament wil bepaalde optrede voorskryf wanneer die persoon onbevoeg geraak het om enige besluite te neem (Hertogh et al. 2007a:49; Gastmans \& De Lepeleire 2009: $1,3)$. Hierdie lewende testament moet in ' $n$ latere situasie as die inkompetente pasiënt se kompetente wil geïnterpreteer word. Die idee van 'n lewende testament is deur die filosoof Ronald Dworkin uitgewerk en word verstaan as voorafbepaalde outonomie (precedent autonomy). Hierdie versoek is nie afdwingbaar nie (Hertogh et al. 2007a:49). Die geneesheer is nie verplig om eutanasie uit te voer nie en geen pasiënt het 'n reg op aktiewe eutanasie en hulp by selfdoding nie (Nederland 2009a:6-7).

Krities in die verstaan van die Nederlandse wetgewing is dat eutanasie en geneesheer-geassisteerde selfdoding ' $n$ kriminele oortreding is ${ }^{4}$ tensy die geneesheer kan aandui dat hy aan bepaalde prosedures voldoen het. Die praktyk van genadedood word dan gesien as die uitsondering op die reël (Hertogh et al. 2007a:49). Die reël is dat 'n mens nie wederregtelik doodgemaak mag word nie (Regionale Toetsingscommissies Euthanasie 2009:33; Nederland 2009b). ${ }^{5}$ Wanneer eutanasie aan bepaalde sorgvuldigheidseise voldoen, word die praktyk as 'n wettige uitsondering beskou.

2.Studies het aangedui dat passiewe eutanasie op pasiënte met demensie meer algemeen voorkom as die onthouding van medisyne wat die lewe sou verleng soos buisvoeding, antibiotika, hospitalisasie en chirurgiese intervensie (Rurup et al. 2005:1142).

3.Nederland (2009b): 'Indien de patiënt van zestien jaren of ouder niet langer in staat is zijn wil te uiten, maar voordat hij in die staat geraakte tot een redelijke waardering van zijn belangen terzake in staat werd geacht, en een schriftelijke de arts aan dit verzoek gevolg geven. De zorgvuldigheidseisen, bedoeld in het eerste lid, zijn van overeenkomstige toepassing.'

4.Volgens die Nederlandse Strafwet, artikels 293 en 294 (Nederland 2009a:12).

5.'In de hiervoor genoemde wetsartikelen is deze uitzondering als bijzondere strafuitsluitingsgrond opgenomen' (Regionale Toetsingscommissies Euthanasie 2009:33).
Die sorgvuldigheidseise ${ }^{6}$ soos deur die wet voorgeskryf, is soos volg:

- de arts heeft de overtuiging gekregen dat er sprake was van een vrijwillig en weloverwogen verzoek van de patiënt

- de arts heeft de overtuiging gekregen dat er sprake was van uitzichtloos en ondraaglijk lijden van de patiënt

- de arts heeft de patiënt voorgelicht over de situatie waarin deze zich bevond en over diens vooruitzichten

- de arts is met de patiënt tot de overtuiging gekomen dat er voor de situatie waarin deze zich bevond geen redelijke andere oplossing was

- de arts heeft ten minste één andere, onafhankelijke arts geraadpleegd, die de patiënt heeft gezien en schriftelijk zijn oordeel heeft gegeven over de zorgvuldigheidseisen

- de arts heeft de levensbeëindiging of hulp bij zelfdoding medisch zorgvuldig uitgevoerd.(Nederland 2009a:4, 12-13, 2009b; vgl. ook Hertogh et al. 2007a:49; Rietjens et al. 2009:273)

Wanneer aan hierdie eise voldoen word, dan is eutanasie 'n uitsonderlike handeling en nie 'n vervolgbare misdaad nie (Rurup et al. 2005:1138) en word dit in Nederland as 'n ultimum remedium beskou.

Die prosedure met betrekking tot eutanasie in Nederland is kortliks soos volg: Nadat die versoekte eutanasieproses afgehandel is, stel die geneesheer 'n verslag op. Die doktersverslag sluit die wilsverklaring van die pasiënt (hoewel dit nie verpligtend is nie), 'n kort mediese geskiedenis asook 'n verslag van die onafhanklike medikus en indien nodig, ander mediese spesialiste in. Die verslag word aan 'n staatslykskouer oorhandig. Die lykskouer stel vas watter middel gebruik is om die eutanasie uit te voer en gaan ook na of die geneesheer die nodige verslag volledig ingevul het. Die lykskouer voeg sy verslag en die verslag van die geneesheer wat die prosedure uitgevoer het by mekaar en stuur dit na 'n kommissie bekend as die Regionale Toetsingscommissies Euthanasie (Nederland 2009a:16; Sorgdrager 2008). Dit is die taak van die kommissie om vas te stel of die geneesheer voldoen het aan die vereistes soos deur die wet beskryf. Die kommissie moet oordeel of die geneesheer aan die sorgvuldigheidseise voldoen het. Indien die kommissie oordeel dat die geneesheer nie aan die eise van die wet voldoen het nie, word die betrokke geval na die vervolgingsgesag gestuur om te oordeel of die verantwoordelike dokter vervolg moet word, al dan nie. Nederland het vyf streekskommissies, bestaande uit 'n voorsitter ('n juris), 'n geneesheer en 'n etikus. Elke kommissie het ook 'n raadgewer met slegs 'n raadgewende stem (Nederland 2009a:18). Die vyf streekskommissies stel jaarliks 'n gesamentlike oorsigtelike verslag op wat deur middel van die internet (www.toetsingscommissieseuthanasie.nl) aan die publiek beskikbaar gestel word. Vanaf 2002 tot 2008 het 13890 mense deur middel van vrywillige aktiewe eutanasie gesterf (vgl. Regionale Toetsingscommissies Euthanasie 6.Staan in Engels ook bekend as rules of due care (Hertogh et al. 2007a:49). 
2006-2009), hoewel Feinberg en Feinberg (1993:101) beweer dat tot 6000 mense per jaar deur middel van eutanasie sterf. ${ }^{7}$

\section{Eutanasie uitgevoer op pasiënte met demensie in Nederland}

\section{Demensie as siektetoestand}

- Demensie word gediagnoseer wanneer die verlies aan intellektuele funksionering so intens is dat dit met die sosiale of beroepsfunksionering van die individu inmeng. Vervolgens word simptome kenmerkend van demensie aangedui.

- Afstomping van geheue is dikwels die mees opmerklike simptoom (Baldwin 1995:293; Dementia 2002:27; Taking Care 2005:206). Die individu vergeet name, telefoonnommers, geboortedatums, onlangse gesprekke en gebeure. Persone sukkel met korttermyngeheue (kan nie nuwe inligting aanleer nie) en langtermyngeheue (kan nie inligting uit die verlede herroep nie).

- Abstrakte denke word op verskeie maniere beïnvloed (Baldwin 1995:293; Dementia 2002:25, 27). 'n Spreekwoord word letterlikverstaan en pasiëntesukkelomooreenkomste en verskille tussen voorwerpe (bv. woorde) aan te dui. Die oordeelsvermoë en impulskontrole is gewoonlik ook aangetas (Baldwin 1995:293; Dementia 2002:25, 27). Die persoon sal etiese reëls begin verontagsaam, persoonlike higiëne verwaarloos, ontoepaslike grappe vertel en obsene taal gebruik.

- Die hoër kortikale funksies word aangetas. Hoewel taalversteurings nie altyd voorkom nie, word dit meer gereeld aangetref en strek dit van vae stereotipe taalgebruik tot afasie en mutisme (Dementia 2002:28; Taking Care 2005:206). Die voorkoms van agnosie (die onvermoë om voorwerpe, ongeag intakte sensoriese funksionering, te herken) en apraksie (die onvermoë om in die afwesigheid van verlamming of sensoriese versteuring betekenisvolle bewegings uit te voer) is ook moontlik. Persoonlikheidsveranderings kom ook byna altyd voor (Baldwin 1995:293; Dementia 2002:27). 'n Aktiewe persoon word apaties en sal hom of haar aan die omgewing onttrek. Pasiënte word deur die familie as 'nie homself nie' ervaar.

- Gepaardgaande kenmerke wat kan ontwikkel, is onder meer angs en depressie (Taking Care 2005:110-111). Paranoïede gedrag kom ook voor. Daarby is persone met demensie besonder sensitief vir fisiese en psigologiese stres. Inkontinensie kom ook gereeld voor. Woede en geïrriteerdheid kom reëlmatig voor (Dementia 2002:27).

- Die diagnose van demensie is ' $n$ komplekse en tydrowende proses wat bestaan uit' $n$ spektrum van kliniese insluitingsen uitsluitingskriteria, asook neuropsigologiese en radiologiese toetse. Die akkuraatheid van die diagnose is

7.Dit is goed om daarvan kennis te neem dat die Health Council of the Netherlands, Royal Netherlands Society for the Advancement of Medicine (KNMG) en Dutch
Association of Nursing Home Medical Practitioners (NVVA) hulle uitgespreek het Association of Nursing Home Medical Practitioners (NVVA) hulle uitgespreek het
téén eutanasie op versoek aan pasiënte met demensie (Dementia 2002:111). taasgenoemde is ook die standpunt van The President's Council on Bioethics wat deur die vorige Amerikaanse president (George Bush) aangewys is om die versorging van bejaardes te ondersoek (Taking Care 2005:47, 127, 209). tussen 65.0\% - 90.0\% (Dementia 2002:55-56). 'n Diagnose is slegs moontlik indien die individu duidelike kognitiewe en nie-kognitiewe simptome vertoon (Dementia 2002:109). Die presiese duur van demensie is onseker, omdat twyfel bestaan presies wanneer die siekte begin. Die agteruitgang is soms vir jare sigbaar voordat die diagnose gemaak word (Dementia 2002:26). Ongeveer vyf jaar na diagnose benodig die pasiënt konstante sorg en binne drie jaar hierna tree die dood in (Taking Care 2005:206; Gastmans \& De Lepeleire 2009:2). Dit moet ook in gedagte gehou word dat demensie uit verskillende variasies en stadia bestaan (Sorgdrager 2008) en dat dit 'n progressiewe terminale siektetoestand is (Dementia 2002:25, 103; Taking Care 2005:206).

\section{Eutanasie vir pasiënte met gevorderde demensie}

In Nederland is die toestaan van wettige eutanasie aan persone met demensie 'n uitsondering (Gastmans \& De Lepeleire 2009:1; vgl. ook 'Eutanasie in Nederland sorgvuldigheid maak dit wettig'). Die debat in Nederland oor die toelaatbaarheid van eutanasie vir persone met demensie het al in die begin van die negentigerjare van die vorige eeu begin (Hertogh et al. 2007a:48). Die weg vir eutanasie by persone met demensie is gebaan deur twee hofuitsprake in 1994 (Chabot-saak) en 2002 (Brongersma-saak) wat bepaal het dat lyding as gevolg van 'n nie-somatiese oorsaak (soos ernstige en nie-behandelbare depressie) en lyding wat voortkom uit 'n medies-geklassifiseerde siekte, somaties sowel as psigies, wel vir eutanasie oorweeg mag word (Rietjens et al. 2009:279).

Ongeveer $6.0 \%$ van bejaardes in Nederland tussen die ouderdom van 61 en 92 jaar het reeds 'n lewende testament opgestel wat stipuleer dat eutanasie op hulle toegepas moet word indien hulle met demensie gediagnoseer word en gevorderde demensie begin vertoon. Tot op hede is daar egter nog geen amptelike gevalle van eutanasie aan 'n persoon met gevorderde demensie met 'n lewende testament aan die owerhede gerapporteer nie (Rurup et al. 2005:1139). Nietemin het 'n ondersoek deur Rurup et al. (2006b:1552-1563) aangedui dat 3.0\% van die dokters wat in die tersaaklike studie genader is, aangetoon dat hulle aktiewe eutanasie toegepas het op pasiënte met gevorderde demensie op grond van 'n lewende testament (Gastmans \& De Lepeleire 2009:4). Dit kan dus aanvaar word dat eutanasie wél in enkele gevalle op grond van 'n lewende testament in Nederland plaasgevind het. Dit sluit ook gevalle in waar die dood verhaas word deur die gebruik van morfien (Rurup et al. 2005:1139).

\section{Eutanasie vir pasiënte met vroeë demensie}

Twee gevalle van eutanasie aan pasiënte met vroeë demensie vóór 2004 kon vasgestel word (Hertogh et al. 2007a:5152). Twee jaar na die goedkeuring van die Nederlandse eutanasie-wet (2004), het dit bekend geword dat die Nederlandse vervolgingsgesag besluit het om 'n dokter wat 'n pasiënt met Alzheimer se siekte, vergesel van (vroeë) demensie, gehelp het met selfdoding - nie te vervolg nie. Hierdie pasiënt het aangevoer dat hy die demensieproses by sy vader en moeder intens beleef het en dan hy nie kans 
gesien het om dit self deur te gaan nie. Volgens hom het sy ouers hewig gely en het demensie hulle menswaardigheid aangetas (Jochemsen 2004; Hertogh et al. 2007a:52; Vilela \& Caramelli 2009:263). ${ }^{8}$ In dieselfde jaar het die Regionale Toetsingscommissies Euthanasie gerapporteer van nog 'n pasiënt met vroeë demensie weens Alzheimer se siekte aan wie eutanasie toegedien is (Regionale Toetsingscommissies Euthanasie 2009:15-18; Hertogh et al. 2007a:52).

Dit is moeilik om presies vas te stel aan hoeveel pasiënte met demensie eutanasie toegestaan is. Eutanasie aan persone met demensie is swak gedokumenteer (Hertogh et al. 2007a:51). Nêrens word presiese getalle deur die Nederlandse owerhede gegee nie. In die Regionale Toetsingscommissies Euthanasie se jaarverslae word net sekere gevalle as voorbeelde bespreek om aan te dui hoedanig die geneesheer en kommissies geoordeel het waarom eutanasie toegestaan is. Die kommissie voer self aan dat die bespreking van gevalle slegs illustrasies of voorbeelde is:

Ook vindt soms melding plaats van levensbeëindiging op verzoek of hulp bij zelfdoding bij patiënten die lijden aan een dementieel syndroom. De in 2008 gemelde gevallen zijn door de commissies als zorgvuldig beoordeeld. Casus 1 en 2 zijn daar illustraties van. (Regionale Toetsingscommissies Euthanasie 2009:8) [Lewensbeëindiging op versoek of hulp by selfdoding deur pasiënte met demensie word soms aangemeld. Die gevalle wat in 2008 vermeld is, is deur die kommissies as sorgvuldig beoordeel. Gevalle 1 en 2 is voorbeelde daarvan.]

In 2006 is ses gevalle aangemeld terwyl slegs een geval as illustrasie bespreek word. Neem verder ook in ag dat eutanasie wat uitgevoer is deur die toediening van opiate (pynstillers) aan pasiënte in die algemeen nie aan die owerhede gerapporteer word nie. Slegs eutanasie wat bewerk is deur barbiturate word aangemeld. In 2005 is slegs $80.0 \%$ van alle uitgevoerde eutanasies aan die owerhede gerapporteer (Rietjens et al. 2009:276, 279; vgl. ook Sorgdrager 2008). ${ }^{9}$ Dit sou seker nie onbillik wees om af te lei dat daar moontlik aan baie meer persone met demensie eutanasie toegestaan word as bloot die bespreekte gevalle nie. Waarskynlik is Vandrunen (2009:206) korrek as hy aanvoer dat hierdie aanmeldingsfeit vrae laat onstaan of alle eutanasie werklik vrywillig plaasvind.

Die volgende demensieverwante eutanasie is aangemeld:

- In 2005 is eutanasie op 'n 83-jarige vrou toegepas wat met Lewy-liggaamdemensie gediagnoseer is (vgl. Regionale Toetsingscommissies Euthanasie 2006:9, 16-18).

- Ses gevalle van eutanasie, toegepas op persone met demensie, is in 2006 aangemeld. Vyf van die gevalle is in 2006 voltrek en een in 2007 (Regionale Toetsingscommissies Euthanasie 2007:5, 18). ${ }^{10}$

- In 2007 is twee gevalle van pasiënte met demensie aan wie eutanasie toegestaan is, bespreek (Regionale Toetsingscommissies Euthanasie 2008:9, 11).

8.Daar is sommige medici wat beweer dat hierdie pasiënt heel warskynlik nie Alzheimer se siekte onder lede gehad het nie (Hertogh et al. 2007a:52).

9.Rurup et al. (2005:1139) praat van 'n aanmeldingsyfer van 54.0\%.

10.'In 2006 hebben de commissies 6 meldingen ontvangen van euthanasie bij patiënten met een dementieel syndroom. Dit blijven uitzonderlijke gevallen'
(Regionale Toetsingscommissies Euthanasie 2007:5). Slegs een geval word in die (Regionale Toetsingscommissies Euthanasie 2007:5). Slegs een geva
Regionale Toetsingscommissies Euthanasie se jaarverslag bespreek.
- In 2008 is twee voorbeelde van eutanasie aan persone met demensie beskryf (Regionale Toetsingscommissies Euthanasie 2009:9-11).

- Boer (2007:64, 2008, 2009a), 'n gereformeerde teoloog en etikus wat self ' $n$ lid van die Regionale Toetsingscommissies Euthanasie is, noem dat jaarliks ongeveer vyf tot agt gevalle van eutanasie aan persone met demensie, aangemeld word. Hy voer egter aan dat 'n stygende lyn waargeneem word. In 2009 is eutanasie op ongeveer nege pasiënte met vroeë demensie uitgevoer (Bartelsman \& Jansma 2010).

In Nederland sterf ongeveer 10000 mense per jaar op natuurlike wyse in die eindfase van demensie (Regionale Toetsingscommissies Euthanasie 2007:5). Dit beteken dat eutanasie slegs aan 'n klein persentasie persone toegestaan word (Hertogh et al. 2007a:54).

\section{Vroeë demensie as grond vir eutanasie}

In die Nederlandse Regionale Toetsingscommissies Euthanasie se jaarverslae (vgl. Regionale Toetsingscommissies Euthanasie 2005-2009) word verskeie pasiënte met demensie aan wie eutanasie toegestaan is, bespreek. Die doel van die bespreking is om ' $n$ verslaggewende verduideliking te gee hoe daar oor versoeke vir eutanasie geoordeel is. Hierdie verslae word nou kortliks opgesom met die doel om vas te stel hoe daar in die Nederlandse praktyk oor demensie en eutanasie gedink en geoordeel word.

By die toestaan van eutanasie aan persone met demensie identifiseer die Regionale Toetsingscommissies Euthanasie twee probleme. Weens die aard van die demensie ontstaan die vraag, in die eerste plek, of daar werklik sprake kan wees van vrywillige versoek of toestemming (Regionale Toetsingscommissies Euthanasie 2007:16; vgl. 'Eutanasie in Nederland - sorgvuldigheid maak dit wettig'). Hierdie probleem word so ver moontlik ondervang deur slegs pasiënte daarvoor te oorweeg wat in 'n vroeë fase van demensie is. Dit beteken dat die persoon se kognitiewe funksionering nog redelik goed is (Bartelsman \& Jansma 2010). Hiermee saam word ook psigiatries bepaal of die versoek tot eutanasie nie deur depressie bepaal word nie. Wanneer depressie vermoed word, sal eutanasie nie oorweeg word nie (Regionale Toetsingscommissies Euthanasie 2008:10-11). Weens die noue statistiese verband tussen selfmoord en depressie is Vandrunen (2009:206; Taking Care 2005:110-111) waarskynlik korrek wanneer hy beweer dat daar moontlik ' $n$ baie groter verband tussen depressie en die versoek tot eutanasie is, as wat erken word. Daarom spreek hy sy ernstige twyfel uit oor die werklik rasionele en kompetente vermoë tydens die versoek tot eutanasie. Verder moet die geneesheer ook seker wees dat die pasiënt onder geen eksterne druk, van byvoorbeeld die familie, is om eutanasie te oorweeg nie. Herhaalde gesprekke tussen die geneesheer en die pasiënt is van uiterste belang (Nederland 2009b:13, Sorgdrager 2008).

In die tweede plek word in die jaarverslae erken dat by pasiënte met demensie die kriterium van vooruitsiglose en ondraaglike lyding (vgl. 'Eutanasie in Nederland - 
sorgvuldigheid maak dit wettig') 'n baie ingewikkelde saak is. Dit is moeilik vasstelbaar juis omdat vooruitsigloosheid en ondraaglikheid ' $n$ persoonsgebonde en subjektiewe begrip is (Nederland 2009b:14). Om ' $\mathrm{n}$ hopelose of vooruitsiglose situasie te bepaal, is ietwat makliker omdat hierdie toestand ongeneesbaar en' $n$ objektiewe feit is. Dit kan ook nie definitief uitgesluit word dat sommige pasiënte hulle toestand as hopeloos sal ervaar nie (Dementia 2002:107). Dit is moeiliker om die ondraaglikheid van lyding vas te stel. Eutanasie word oor die algemeen makliker en vinniger toegepas by pasiënte met erge lyding weens een of ander fisiese siekte en simptome en hewige funksieverlies en met ' $n$ relatief kort lewensverwagting. In Nederland word eutanasie die meeste toegepas op pasiënte met kanker. In sodanige gevalle is daar relatief min debat daaroor of lyding ondraaglik was of nie. Volgens Rietjens et al. (2009:279) dui navorsing daarop dat by grensgevalsituasies soos eutanasie by demensiepasiënte, daar meer dikwels 'n interpretasieverskil tussen die geneesheer en die pasiënt se persepsie van ondraaglikheid ontstaan. Die Regionale Toetsingscommissies Euthanasie waarsku alle persone betrokke by eutanasie dus dat versoeke vir eutanasie deur pasiënte met demensie baie versigtig en met groot terughoudenheid hanteer moet word (Sorgdrager 2008). Die betrokke geneesheer word aangespoor om deskundiges in te roep om te help adviseer of die pasiënt aan die nodige kriteria voldoen. Die geneesheer, 'n kollega en ander deskundiges moet dan saam bepaal of die versoek vrywillig is en of daar van uitsiglose en ondraaglike lyding sprake is (Regionale Toetsingscommissies Euthanasie 2008:8-9, 2009:8).

Vir die Toetsingskommissie is die oorweging van drie uitgangspunte in die bepaling van die ondraaglikheid van lyding baie belangrik. Eerstens is die pasiënt se perspektief en belewing van sy lyding, naamlik hoe die pasiënt fisies, psigies en geestelik uitdrukking gee aan sy belewing van (uitsigloosheid en) ondraaglikheid. 'n Besondere aspek van ondraaglike lyding wat deur die geneesheer in ag geneem moet word, is die feit dat ' $n$ individu soms ' $n$ intense vernedering mag ervaar (Dementia 2002:106). Hertogh et al. (2007a:49) is van oordeel dat die pasiënt se persoonlike oordeel eerste kom en vermoedelik die sterkste sal weeg (vgl. ook Nederland 2009b:14). Sorgdrager (2008) verskil hiervan en meen dat die finale besluitneming by die geneesheer lê.

Tweedens moet die geneesheer so ver moontlik die ondraaglikheid van die lyding kan invoel of meevoel (Regionale Toetsingscommissies Euthanasie 2005:16, 2006:18-19). ${ }^{11}$ Die begrip meevoel of invoel verraai klaar die subjektiwiteit van die proses en dit is duidelik dat geen objektiewe instrument bestaan om die intensiteit van lyding van ' $n$ ander persoon te bepaal nie. Wat vir een persoon draaglik is, is vir 'n ander persoon ondraaglik en vice versa (Regionale Toetsingscommissies Euthanasie 2005:16, 2006:19, 2007:19). Sommige persone meen dat ondraaglikheid 'n saak is wat die geneesheer baie moeilik kan assesseer en dit moet daarom aan die oordeel van die pasiënt oorgelaat word (Rietjens et al. 2009:280). Hoewel lyding 'n subjektiewe saak is, kan die uitdrukking van lyding wel objektief bepaal word

11.'De commissies gaan bij de beoordeling na of de ondraaglijkheid van het lijden invoelbaar is geweest voor de arts' (Regionale Toetsingscommissies Euthanasie 2007:20).
(Dementia 2002:107). Voortdurende, diepgaande en gereelde kommunikasie tussen die pasiënt en die geneesheer is dus van uiterste belang. Hiersonder kan geen redelike oordeel oor die lyding van die pasiënt gemaak word nie (Rurup et al., 2005:1139; Hertogh et al. 2007a:49). Dit moet ook in gedagte gehou word dat die geneesheer die pasiënt, sy persoonlikheid en geskiedenis redelik goed ken (Nederland 2009b:14). Derdens is dit belangrik om daarop te wys dat die vierde sorgvuldigheidseis duidelik op die gesamentlike besluitnemingsproses wys (Hertogh et al. 2007a:49). Hierdie eis is na alle waarskynlikheid die enigste reël wat'n mate van objektiwiteit aan die beoordelingsproses verleen.

Uit die bespreking van 'n aantal voorbeelde uit die jaarverslae van die Regionale Toetsingscommissies Euthanasie, kan die volgende afleidings gemaak word oor die begronding of regverdiging van eutanasie (ook genoem kliniese oordeel) aan persone met demensie. Hierdie is dus argumente wat deur die pasiënt en geneesheer aangevoer is en wat uiteindelik tot eutanasie gelei het:

- Pasiënte se dimensie hou verband met:

- Alzheimer se siekte (met 'n relatiewe kort lewensverwagting).

- Lewy-liggaam se siekte.

- Op grond van die volgende beredenering beoordeel die Regionale Toetsingscommissies Euthanasie dat die pasiënt se besluit as vrywillig en goed oorweeg word:

- $\mathrm{Al}$ die versoeke is van pasiënte wat in die vroeë fase van demensie gediagnoseer is (Bartelsman \& Jansma 2010).

- Bewustelike en herhaalde mondelinge en skriftelike versoeke tot eutanasie is tot die huisdokter gerig (Bartelsman \& Jansma 2010).

- Pasiënte is heeltemal bewus van die betekenis (strekking) en gevolge van hulle besluit. Pasiënte vertoon 'n redelike logiese gedagtegang.

- Pasiënte is deeglike bewus van hulle toestand en het insig in die siekte en die simptome daarvan. Daar is 'n duidelike besef van die onvermydelike aftakeling, simptome van verlies van oriëntasie en persoonlikheid. Pasiënte dui duidelik aan dat hulle nie die siekteproses tot die einde wil deurmaak nie. Pasiënte is bewus dat die toestand ' $n$ progressiewe karakter het.

- Die pasiënt besef dat geen effektiewe behandelingsopsie bestaan het nie.

- Eutanasie is 'n manier om kontrole oor die lewe tot die einde te behou (vgl. ook Taking Care 2005:42).

- Op grond van die volgende beredenering beoordeel die Regionale Toetsingscommissies Euthanasie dat die pasiënt uitsiglose ${ }^{12}$ en ondraaglike ${ }^{13}$ lyding $^{14}$ ervaar het:

12. Haar lijden onder haar dementie was uitzichtloos nu het de verwachting was dat het beeld verder zou verergeren en patiënte uiteindelijk verpleegbehoeftig zou worden, hetgeen zij absoluut niet wilde' (Regionale Toetsingscommissies Euthanasie 2006:17).

13.'Daarnaast is in het bijzonder de vraag aan de orde of er sprake is van ondraaglijk lijden bij patiënten met dementia' (Regionale Toetsingscommissies Euthanasie 2007:20) en 'Uiteindelijk raakten de verpleging, de arts en de psycholoog ervan overtuigd dat de patiënt ondraaglijk leed ten gevolge van de dementie en dat hij een oprechte doodswens had' (Regionale Toetsingscommissies Euthanasie 2009:10).

14.Die Nederlandse mediese raad oordeel soos volg oor vroeë demensie en lyding: The standpoint that patients in the initial phase of dementia experience unbearable suffering is, in the Committee's view, generally incorrect. The Committee does not suffering is, in the Committee's view, generally incorrect. The Committee does not
exclude the possibility that assisted suicide could be within the terms of the law in individual cases. (Dementia 2002:110) 
- Uitsigloosheid: Die pasiënt besef dat, redelik geoordeel, geen kans op enige verbetering of genesing bestaan nie. Die pasiënt besit 'n gevoel van totale vooruitsigloosheid. Die pasiënt besef ook dat simptome nie versag kan word nie. Uitsigloosheid word ook deur 'n diagnose van Alzheimer se siekte bepaal, waarvoor daar tans geen genesing moontlik is nie en waartydens die pasiënt progressief agteruitgaan.

- Ondraaglikheid in die huidige situasie: Die pasiënt se kognitiewe vermoëns is aangetas. Pasiënte sukkel intens met afnemende beheer oor gedagtes, intense geheueprobleme (vergeetagtigheid) en sommige pasiënte erken nie meer hulle kinders nie. Oriëntasie ten opsigte van tyd en plek word 'n groter probleem. Pasiënte ondervind ernstige probleme om die verband tussen dinge en gebeure in te sien, en kan nie konsentreer nie (hulle kan daarom nie lees en televisie kyk nie). Verder sukkel hulle om te tel, hulle kommunikasie verswak, hulle praat sporadies onsamehangend, sukkel om die regte woorde te vind en verloor gereeld die draad van die gesprek. Baie pasiënte raak verward (ontredder) en voel daarom deur die wêreld bedreig. Vir sommige pasiënte was totale beheer oor hulle geestelike vermoëns van die uiterste belang. Die pasiënte voel dat hy of sy gek word van al die chaos in hulle kop. Sommige pasiënte ervaar intense angs en wanhopigheid. Heelwat pasiënte begin kontrole of beheer oor hulle identiteit verloor. Die pasiënt ervaar'n verlies aan selfstandigheid. Die pasiënte was gewoond om in totale onafhanklikheid te funksioneer, maar is nou vir hulle daaglikse aktiwiteite grootliks van ander mense afhanklik (Baldwin 1995:293). Die pasiënte voel hulle vryheid is beperk. Hulle begin beheer oor hulle lewe en vaardighede verloor (Dementia 2002:108). Die pasiënt ervaar 'n verlies van selfstandigheid. Die pasiënte was daaraan gewoond om in totale onafhanklikheid te funksioneer. Hulle funksioneer nie meer selfstandig (outonomie) nie en is nou vir hulle daaglikse aktiwiteite grootliks van ander mense afhanklik (Baldwin 1995:293). Die pasiënte voel hulle vryheid is beperk. Hulle begin beheer oor hulle lewe en vaardighede verloor (Dementia 2002:108). Die pasiënt ervaar 'n verlies van waardigheid. Verskeie pasiënte vertoon 'n besef van, en beleef aftakeling, verlies aan dekorum (fatsoenlikheid), selfrespek en waardigheid (vgl. ook Dementia 2002:108). Die pasiënt ervaar algemene probleme. Baie pasiënte voer aan dat hulle intens sosiaal geïsoleerd raak (Taking Care 2005:111); die lewe voel te moeilik en hulle sien nie meer daarvoor kans nie. Agteruitgang oor 'n relatiewe kort tydperk is waarneembaar en verskeie pasiënte het voorheen soortgelyke agteruitgang by naby familielede ervaar.

- Ondraaglikheid oor die toekomstige situasie: ${ }^{15}$ Pasiënte vertoon insig dat hulle toekomstige lewenskwaliteit drasties sal versleg. Hulle besef dat hulle binne 'n afsienbare tyd 'n verplegingsbehoeftige sal word. Dit beteken dat pasiënte nie self sal kan eet of hulself

15.'Het vooruitzicht (Beklemtoning - ALR) dat hij op termijn het vermogen alledaagse handelingen uit te voeren ging verliezen en hij met wassen, aankleden en eten moest worden geholpen was voor hem een mensonterende en ondraaglijke moest worden geholpen was voor hem een mensonterende en ondraaglijke
gedachte' (Regionale Toetsingscommissies Euthanasie 2009:9; vgl. ook Dementia gedachte' (Regionale Toetsingscommissies Euthan
2002:107; Taking Care 2005:42; Sorgdrager 2008). meer sal kan was of aantrek nie. 'n Intense vrees ontstaan omdat hulle bang is dat hulle in die toekoms fisies swak versorg sal word en totaal sal vereensaam (Taking Care 2005:111; Bartelsman \& Jansma 2010). Vrees ontstaan omdat die pasiënte nie in 'n situasie wil wees waar hulle nie meer besluite oor hulleself sal kan neem nie. Pasiënte wil nie toekomstige intellektuele aftakeling beleef nie en wil nie in die toekoms in 'n fase van nutteloosheid inbeweeg nie. Baie pasiënte het die proses van demensie by naby familielede beleef. Volgens Sorgdrager (2008), tien jaar voorsitter van 'n Regionale Toetsingscommissies Euthanasie, was hierdie bewustheid 'n groot oorsaak van ondraaglike lyding by pasiënte met demensie (vgl. ook Bartelsman \& Jansma 2010).

- Pasiënte se ouderdomme het gewissel tussen 65 en 80 jaar en was van albei geslagte.

- Voordat eutanasie aan persone met demensie toegestaan is, het die verantwoordelike dokter deeglik van deskundige advies gebruik gemaak.

Dit is duidelik dat die Nederlandse owerhede heeltemal oortuig is dat pasiënte met vroeë demensie se lyding (soms) van so ' $n$ aard is dat eutanasie aan hulle toegestaan mag word. Hulle oordeel soos volg:

Daarnaast is in het bijzonder de vraag aan de orde of er sprake is van ondraaglijk lijden bij patiënten met dementie. Wanneer een patiënt zich bewust is van zijn ziekte en de vooruitzichten daarvan, kan een grote, actuele lijdensdruk ontstaan. (Regionale Toetsingscommissies Euthanasie 2007:20; Sorgdrager 2008) [Daarby is die besondere vraag aan die orde naamlik of daar sprake is van ondraaglike lyding by pasiënte met demensie. Wanneer 'n pasiënt bewus is van sy siekte en die vooruitsigte daarvan, kan oorweldigende geesteskwelling ontstaan.]

Dit is betekenisvol om op hierdie stadium daarop te wys dat medici soos Hertogh et al. (2007a:51-53) dit bevraagteken of vroeë demensie werklik diagnosties vasgestel kan word. Volgens hulle is daar geen diagnostiese gereedskap om te bepaal of matige kognitiewe probleme (soos geheueprobleme, ens.) noodwendig vroeë demensie is nie (Dementia 2002:54). Hiermee saam is daar ook geen instrument om te bepaal of klagtes van matige kognitiewe (ouderdomverwante) probleme inderdaad tot volgroeide demensie sal ontwikkel nie (Baldwin 1995:294; Dementia 2002:54). Hulle twyfel of bogenoemde simptome werklik demensieverwant is. Uit 'n etiese oogpunt moet hierdie feit deeglik verreken word (Dementia 2002:109-110). Dit val buite die bestek van die hierdie artikel, asook die bekwaamheid van die skrywer om wetenskaplik hieroor te oordeel. Wat wel redelik duidelik is, is dat die Regionale Toetsingscommissies Euthanasie met hulle span kundiges oordeel en dit so beskryf dat eutanasie wel toegestaan is op grond van demensie (verwante simptome) en gepaardgaande lyding (vgl. ook Sorgdrager 2008).

\section{Samevatting}

Eutanasie is vir baie jare deel van die moraal van die Nederlandse samelewing, maar is eers in 2002 wetlik gereguleer. Vanaf ongeveer 2004 word gereeld indikasie gevind dat vrywillige eutanasie ook op pasiënte met demensie uitgevoer is, hoewel dit waarskynlik al vroeër plaasgevind het. 


\section{Die etiek van eutanasie aan pasiënte met demensie Inleidend}

In hierdie afdeling sal aandag gegee word aan die etiese beoordeling van eutanasie aan pasiënte met gevorderde en vroeë demensie. Dit is reeds genoem dat hierdie beoordeling vanuit 'n gereformeerde teologiese perspektief gedoen sal word (vgl. 'Eutanasie vir pasiënte met demensie - 'n aktuele vraagstuk'). Die uitgangspunt van hierdie artikel is dat die Bybel die Woord van God is (1 Tess 2:13; vgl. Van Wyk 1986:16; De Bruyn 1993:2) waarin sy wil gevind word (Ps 119:105) en wat beteken dat God openbaar wat goed en kwaad is (Miga 6:8). Argumente vir en teen eutanasie sal ook hanteer word (Heyns 1986:333).

\section{Beoordeling van eutanasie by pasiënte met gevorderde demensie}

Daar is reeds daarna verwys dat verskeie individue in Nederland lewende testamente opgestel het waarin hulle stipuleer dat wanneer hulle 'n gevorderde stadium van demensie bereik het, eutanasie op hulle toegepas moet word. Daar is ook studies wat aantoon dat eutanasie op grond van sodanige lewende testament wel plaasgevind het (vgl. 'Eutanasie vir pasiënte met gevorderde demensie').

Sommige etici meen dat eutanasie aan pasiënte met gevorderde dimensie op grond van 'n lewende testament oneties is, juis omdat dit geneeshere en gevolmagtigdes dwing en van hulle verwag om inhumane of wrede besluite te neem (Hertogh et al. 2007b:5). Eerstens word die geneesheer en gevolmagtigdes voor die keuse geplaas om te bepaal en te oordeel wat weeg die swaarste, naamlik die lewende testament of die huidige situasie van die (inkompetente) pasiënt met demensie. Volgens kliniese ervaring wys Hertogh et al. (2007a:50) dat dit gebeur dat die (inkompetente) pasiënte soms hulle testament weerspreek, of dat die pasiënt intussen (optimaal) aangepas het by die omstandighede wat hy in die testament veroordeel het en selfs 'inwillig' om versorg te word. Die persoon met demensie word psigologies ' $n$ ander persoon as die vroeër kompetente persoon (Rurup et al. 2005:1143) en so 'n ander persoon kan by sy nuwe omstandighede aanpas: '... our anticipatory beliefs often fail to recognize our ability to adapt' (Hertogh et al. 2007b:4). Navorsing toon dat sommige inkompetente pasiënte lewendig en met matige bewustheid aktief werk tot in die gevorderde fase van demensie.

Tweedens, indien die geneesheer en die gevolmagtigdes kies om wel uitvoering aan die testament te gee, ontstaan die dilemma, naamlik presies wanneer die versoek tot eutanasie uitgevoer moet word. Dit plaas die geneesheer en gevolmagtigdes voor 'n probleem om te bepaal wanneer die toestand van die pasiënt voldoen aan die kriteria soos in die testament gestipuleer. Die pasiënt met demensie verwag dus nou van iemand anders om sy of haar moment van dood te bepaal. Bogenoemde twee dilemmas roep die volgende etiese vraag volgens Hertogh et al. (2007a) na vore:
... how far do we allow each other to go in what we ask for our fellow man in view of our self-determination or, more specifically in view of our supposed right to self-controlled death? (p. 50)

Hoewel die bogenoemde vraag geldig is, is dit te betwyfel of hierdie dilemmas sterk genoeg weeg om eutanasie op grond van 'n lewende testament af te wys. 'This is difficult but not impossible' skryf die Nederlandse Mediese Raad in verband met die uitvoering van 'n lewende testament (Dementia 2002:11). Die praktyk in Nederland dui tans daarop dat sommige geneeshere tog aan die lewende testament uitvoering sal gee en die moment van die dood sal kies (vgl. 'Eutanasie vir pasiënte met gevorderde demensie'). Ten opsigte van die eerste dilemma kan aangevoer word dat die Nederlandse Eutanasie Vereniging hierdie nie as 'n probleem beskou nie en aanvoer dat die lewende testament die voorafbepaalde outonomie (precedent autonomy) van die pasiënt verteenwoordig. Dit beteken dat ongeag die (inkompetente) pasiënt se huidige wense of toestand, die oorspronklike versoek voor inkompetensie gerespekteer moet word. Die kompetente persoon het ook die adaptasie argument oorweeg. Die vroeër kompetente persoon wat die lewende testament maksimaal bewustelik opgestel het, versoek die geneesheer en ander gevolmagtigdes, om alle huidige uitlatings en adaptasies te ignoreer behalwe uitsprake wat in konformiteit (ooreenstemming) met die lewende testament is. Met die lewende testament het die pasiënt erken dat sy deel van die dialoog om ondraaglikheid en hopeloosheid van lyding aan te dui, afgehandel is.

Ook wat die tweede probleem betref moet aanvaar word dat baie dokters dit moeilik sal vind om die oomblik van dood te kies. Dit kan beweer word dat, hoewel hierdie versoek deur sommige as eties onaanvaarbaar beskou word, daar wel geneeshere en gevolmagtigdes sal wees wat geen etiese probleem daarmee sal ondervind om die moment van dood te bepaal nie. Tot ' $n$ groot mate besluit die dokter in elk geval oor die datum van dood by 'n persoon met vroeë demensie. Dit neem soms jare voor die geneesheer aan die pasiënt se versoek voldoen (Regionale Toetsingscommissies Euthanasie 2008:10). Die besluit vind immers nie plaas in 'n situasie van geen toestemming nie. In die huidige praktyk van eutanasie by pasiënte gebeur dit dat geneeshere verskeie ander kundiges gebruik om te help oordeel oor uitsigloosheid en ondraaglikheid van lyding met die oog op eutanasie (vgl. Nederland 2009b:25-26). Die Nederlandse Mediese Raad wys daarop dat 'n lewende testament altyd 'n vorm van interpretasie benodig. Die geneesheer kan deur 'n kundige span met die interpretasie gehelp word. Dit beteken dat die besluit nie alleen geneem word nie (Dementia 2002:110).

In aansluiting by bogenoemde argumente word ook aangevoer dat persone met gevorderde demensie nie meer ondraaglike en hopelose lyding beleef nie (Rurup et al. 2005:1139; Hertogh et al. 2007a:50). Verskeie geneeshere en kundiges in die veld van demensie wys daarop dat die persoon met demensie al hoe minder insig (anosognosie) in hulle kognitiewe en funksionele toestand vertoon. Die implikasie hiervan is dat die pasiënt se subjektiewe ervaring van sy siekte progressief verminder en dat dit onmoontlik 
is vir 'n pasiënt met gevorderde demensie om sy situasie as ondraaglik en hopeloos te ervaar. Dit impliseer verder dat die pasiënt met demensie nie werklik ly nie (Dementia 2002:107). Die argument is dat eutanasie aan pasiënte met gevorderde demensie binne konteks van die Nederlandse wetgewing onwettig en oneties is, omdat die pasiënt nie regtig ly nie en die geneesheer dan ook nie kan bepaal dat die pasiënt ly nie (Dementia 2002:111). Hierdie argument is ook nie heeltemal waar nie, omdat'n onlangse studie van Rurup et al. (2005:11381144) op die teendeel gedui het. Hierdie navorsers het 577 geneeshere wat met pasiënte met demensie werk, ondervra. Van hierdie geneeshere het $25.0 \%$ aangedui dat hulle van mening is dat van hulle pasiënte met'n lewende testament wat gesterf het, ondraaglik gely het, terwyl 50.0\% aangedui het dat volgens hulle oordeel van hierdie pasiënte se lyding hulle uitsigloos gelaat het. Volgens die studie is lyding veroorsaak deur asemhalingsprobleme, krampe en sametrekkings, geïrriteerdheid, bewerasie en verbouereerdheid asook pyn en angs. Lyding word ook veroorsaak deur hartseer, honger en dors (Dementia 2002:107-108). Dit is waarskynlik waar dat pasiënte die lyding wat met demensie gepaard gaan nie so direk ervaar nie en daarom ook nie verbaliseer nie. Omdat hulle nie so wil lewe nie het sulke pasiënte juis 'n lewende testament opgestel.

Na die stel van rasionele argumente vir en teen eutanasie by gevorderde demensie, word nou oorgegaan na die beoordeling van eutanasie by pasiënte met vroeë demensie. Om eutanasie by gevorderde demensie sowel as by vroeë demensie te beoordeel, word die Skrif gebruik.

\section{Beoordeling van eutanasie by pasiënte met vroeë demensie}

Mag 'n persoon met vroeë of gevorderde demensie eutanasie gebruik om hulle dood te bepaal? Mag eutanasie op aanvraag plaasvind? Van Wyk (1998:123) vra of eutanasie nie 'as hoë uitsondering, as uiterste randverskynsel mag voorkom nie', maar huiwer om 'ja' op hierdie retoriese vraag te antwoord. Die vraagstuk van eutanasie is 'n komplekse en moeilike probleem (Cameron 1995:357) en daar moet gewaak word teen simplistiese antwoorde (Vandrunen 2009:197).

Vandrunen (2009:197) is korrek as hy aanvoer dat probleme rondom eutanasie ons terugneem na die basiese vrae rondom selfmoord of selfdoding. Wanneer na die Christelike tradisie geluister word, blyk Skrifinterpretasie dat geen reg tot selfdoding of eutanasie afgelei kan word nie (Boer 2002). Selfdoding misken die soewereiniteit van God om oor die dood te besluit (Harris 1995:825). Die Bybel bevat inderdaad verskillende verhale van mense wat na hulle dood verlang, soos die depressiewe Elia (1 Kon 19:4), Simeon (Luk 2:29) en Paulus (Fil 1:23). Verder word daar ook insidentele voorbeelde gevind van mense wat hulleself dood gemaak het, naamlik Abimelek (Rig 9), Agitofel (2 Sam 1), Simri (1 Kon 16), Saul (1 Sam 31) en Judas. Hoewel selfdoding in laasgenoemde gevalle nie eksplisiet veroordeel word nie (Barth 1961:408; Harris 1995:825), dui die konteks van hierdie gebeure inderdaad op die tragiese aspek van selfdoding (Boer 2002).
Die Christelike kerk het deur die eeue bogenoemde voorbeelde van selfdoding, asook die feit dat die Bybel op geen plek selfdoding uitdruklik verbied nie (Barth 1961:406), in die lig van die sesde gebod beoordeel (Eks 201:13; Matt 5:21-22; 1 Tim 1:9), wat impliseer dat jy nie jouself mag (laat) doodmaak nie (Douma 1992:156; Harris 1995:825). Die sesde gebod stel die grens tussen wat die mens nie mag nie en wat God mag, 'n grens wat nie oorgesteek mag word nie (Pred 8:8; Boer 2007:66; Taking Care 2005:111-112; Vandrunen 2009:198). Sonder twyfel bepaal die sesde gebod dat die mens geen selfbeskikkingsreg oor sy eie lewe het nie (Douma 1992:153). Ook Karl Barth (1961) stel duidelik dat die mens nie die reg en outonomie het om homself en/of haarself (te laat) dood te maak nie:

This freedom (of life) may for the most part be a burden to man. But this does not mean that he can understand it as autonomy, i.e., as the freedom to deny life, to resolve in pretended freedom upon its destruction, and to act accordingly ... Self destruction as the taking of one's one life in this way is clearly self-murder. (p. 405)

In sy motivering vir bogenoemde opmerking verwys Barth na Calvyn se Nostri non sumus sed Domini. Ons behoort dus nie aan onsself nie, maar aan God (Boer 2002) en daarom mag die mens nie oor sy eie lewe beslis nie. God is die Skepper, Gewer en Here van die mens se lewe. God is soewerein oor die mens se lewe en nie die mens self nie. In noue samehang met die sesde gebod het die kerk ook altyd aangevoer dat die mens na die beeld van God geskape is (Gen 1:26-27). Dit hou in dat die mens soos God is en iets van God reflekteer (Cameron 1995:359). Die mens as beeld van God het definitiewe implikasies vir 'n Christelike beskouing van eutanasie (Grogan 1995:477). 'God reveals himself many times in Scriptures as the living God, and his image bearers were created to live', skryf Vandrunen (2009:46). In die konteks van eutanasie dui dit aan dat die mens - soos die lewendige God - hom- of haarself nie aan 'n nie-bestaan (of dood) sal oorgee nie, maar wil lewe en laat lewe. Anders gestel: eutanasie is contra naturam of die natuurwet wat leer dat die mens wil lewe en homself nie wil (meer) skade aandoen nie (Ef 5:29; Douma 1992:156; vgl. ook Taking Care 2005:112). Bogenoemde verstaan van outonomie beteken nie dat die gelowige nie selfbeskikking ken en eerbiedig nie. Outonome handeling is belangrik vir die gelowige om hom of haar teen die ander mens se paternalistiese intervensie te beskerm (Boer 2007:66).

'n Vraag wat nou na vore tree is wat die verhouding tussen (ondraaglike en hopelose; vgl. 'Eutanasie in Nederland sorgvuldigheid maak dit wettig') menslike lyding en die sesde gebod is. 'Over de vraag naar de aard van het lijden dat aanleiding geeft tot een verzoek om euthanasie of hulp bij zelfdoding, is elk woord te veel', skryf Boer (2002). Daar moet met groot sensitiwiteit oor die lyding van ander mense gepraat word (Heyns 1986:334). Tog moet gestel word dat die Christelike kerk (ondraaglike en hopelose) lyding nooit as 'n deurslaggewende argument ten gunste van eutanasie beskou nie. Die begrip lyding is altyd in die lig van die sesde gebod beoordeel en nie omgekeerd nie. Dit beteken 'n mens mag nie doodmaak om lyding te vermy nie. Die mens word geroep 
om die onbegryplikhede van die lewe te dra sonder om dood te maak (Douma 1992:153). Die rede vir hierdie uitgangspunt word Christologies gemotiveer. Vanuit die herskepping van Christus (herstelde verhouding met God) word die gelowige geroep om Christus na te volg deur lyding te verduur soos Hy dit verduur het, met die wonderlike belofte dat ons soos Hy verheerlik sal word (Rom 8:17; Joh 15:20). In bioetiese lydingskonteks beteken dit dat gelowiges soos Christus ook hulle lewenskruis (demensie en simptome) sal dra (Matt 16:24-25) en daarin volhard (Vandrunen 2009:203). Die mens moet sy lyding verwerk soos Christus dit gedoen het deur te sug en te huil, maar nooit deur dood te maak nie (Matt 5:4). Die gelowige kan wel sy lyding aanvaar en verwerk omdat hy weet dat die huidige lyding nie opweeg teen die ewige heerlikheid nie (Rom 8:18; Douma 1997:50). Job het in sy lyding (siekte) (Job 2:7) nooit selfdoding oorweeg nie (Job 2:9-10) ten spyte van die feit dat hy 'n doodsverlange gehad het (Job 3:21-22). In sy lyding het hy beskeie teenoor God gebly (Job 42:2-6; Vandrunen 2009:201-202). Dieselfde argumente ten opsigte van eutanasie en lyding, geld ook mutatis mutandis vir eutanasie en barmhartigheid. Die beoefening van barmhartigheid is ' $n$ kragtige Christelike (Matt 5:7) en universeel-godsdienstige deug (Charter for compassion 2009), maar kan nie as 'n argument ten gunste van eutanasie aangevoer word nie (Matt 5:21-23; Boer 2007:63). Dieselfde geld ook vir die argument dat eutanasie geregverdig is omdat die gelowige reeds die hemel en ewige lewe besit. Nêrens in die Bybel word die opdrag van die sesde gebod in die lig van die leerstuk van die hemel en ewige lewe gerelativeer nie (Boer 2007:63-64).

Uit bogenoemde beredenering is dit duidelik dat eutanasie sonder twyfel nie 'n maklike en vinnige oorweging mag wees nie. Die gronde wat die Nederlandse wet aanvoer ten gunste van eutanasie (vgl. 'Eutanasie in Nederland - sorgvuldigheid maak dit wettig') en argumente wat individuele pasiënte met vroeë demensie aanvoer ten gunste van eutanasie (vgl. 'Vroeë demensie as grond vir eutanasie') sal baie Christengelowiges en etici nie oortuig nie. 'Die nee vir aktiewe genadedood op aanvraag of nie, is waarskynlik die veiligste', skryf De Klerk (1998:151). Aktiewe eutanasie kan niks anders as noetanasie genoem word nie; ' $n$ bedinkte en beplande dood is prinsipieel dus iets anders as die verwagte dood in Christus (Heyns 1986:335).

Beteken dit dat daar geen uitsondering moontlik is nie? Andersen en Hallamaa (1995:68) maak die opmerking dat 'the prohibition of killing has never been obeyed without exceptions' en verwys na oorlog, doodstraf en selfverdediging (vgl. ook Heyns 1986:334). In hulle bespreking van eutanasie dui Boer en Schroten (1996) daarop dat Jesus die gebooie ook nie op 'n absolute wyse hanteer nie - met verwysing na sy hantering van die vierde gebod (Mark 2:23-28). Barth (1961:410-411) meen dat die Christelike etiek in hierdie verband moet erken dat 'n uitsondering moontlik is en verwys na Simson wat homself doelbewus doodgemaak het (Rig 16:30). Ook Boer (2007:65) verwys versigtig na Simson as uitsondering, hoewel hy nie in sy eie lewe die Simson-keuse sou oorweeg nie. Verskeie teoloë is dit eens dat hier nie van selfmoord sprake is nie (Geesink 1931:393; Harris 1995:825), maar van selfdoding met die doel om beter (toekomstige) omstandighede vir die naaste tot stand te bring (Heyns 1970:179-180; Douma 1992:159). Simson het inderdaad sy lewe vir sy naaste gegee (Joh 15:13; Heyns 1986:334; De Bruyn 1993:155). Simson word in die Nuwe Testament as deel van die groot skare geloofsgetuies genoem (Hebr 11:32; 12:1; Douma 1992:157). Dit is opvallend dat Vandrunen (2009:195-207), wat enige uitsondering ten opsigte van selfdoding kategories verwerp en dit as 'n sonde beskou, wel al die ander voorbeelde van selfdoding in die Bybel bespreek, maar glad nie na Simson verwys nie. Die vraag kan gevra word: is Christus nie 'n voorbeeld dat verlossing en nuwe omstandighede soms slegs deur die dood bewerk kan word nie?

Wanneer Barth (1961) die uitsondering oorweeg, noem hy die volgende twee kwalifikasies:

- If the possibility of Samson has sometimes to be considered, it can be only at the extreme limit when others have first been examined with final seriousness and there can be no doubt whatever that this is the will of God and therefore to be adopted.

- While it cannot be denied that there are situations in which God may actually give man the freedom, permission and command to destroy himself ... yet this does not mean that we can decide what these situations are or what kind of self-destruction is not suicide but an act of obedience in harmony with the requirement of respect for life. (p. 411; vgl. ook Boer 2002)

In die lig van bogenoemde beredenering sou daar spekulatief geargumenteer kan word dat 'n persoon met onverwagse vroeë demensie soms in so 'n situasie kan beland waar sy familie om verskeie psigiese, fisiese, sosiale en finansiële redes hulself nie kan versorg nie en waar daar nie goeie alternatiewe versorging moontlik is nie weens die eie finansiële situasie. Die (toekomstige) versorging van 'n persoon met demensie kan die familie wat hom of haar moet versorg onder intense druk en ondraaglike omstandighede plaas. Versorging kan die bestaande ekwilibrium in 'n gesin erg versteur (Dementia 2002:30) en intensiewe huweliks- of familiekonflik veroorsaak. Verskeie pasiënte met demensie wat eutanasie versoek het, het aangedui dat hulle die uitwerking en invloed van demensie by familie beleef het (vgl. 'Eutanasie vir pasiënte met vroeë demensie' en 'Vroeë demensie as grond vir eutanasie'). Navorsing het aangedui dat pasiënte met demensie soms intense druk by familieversorgers kan veroorsaak. Die Nederlandse Mediese Raad het op versoek van die Nederlandse Minister van Gesondheid 'n intensiewe studie gemaak van demensie as verskynsel en het die volgende bevindings gemaak met betrekking tot die impak van die versorging van pasiënte met demensie op die familie: 'Family care is an exceptionally onerous task; one that often has a serious impact on a person's well-being and health' (Dementia 2002:10, 16, 28, 30-31,108, 123).

Dit kan ook gebeur dat daar binne 'n afsienbare tyd geen (goeie) institusionele versorging beskikbaar is nie: 
- The availability of professional care is often of critical importance in determining whether the informal carer is able to continue caring for the patient ... However, that is only an option for those with sufficient financial resources.

- There are still waiting lists for home care, day treatment and admission to an institution ... There is international concern regarding the quality of care for dementia patients in institutions. (vgl. Dementia 2002:31, 108, 119-120)

Hoe beter die vooruitsig op kwaliteitsorg, hoe groter is die kans dat die vraag na eutanasie sal afneem (Dementia 2002:108). As bogenoemde in gedagte gehou word, kan eutanasie van die persoon met demensie in uitsonderlike gevalle tot voordeel en verlossing van sommige families wees. Hier is van selfopoffering sprake. ' $n$ Mens moet erken dat daar in ' $n$ sondige wêreld wel tragiese omstandighede kan ontstaan waar 'n pasiënt met vroeë demensie werklik met sy rug teen die muur staan, met die gevolg dat eutanasie die beste van twee slegte opsies kan wees. In hierdie sin is eutanasie nie ' $n$ keuse teen versorging nie, maar ' $n$ keuse teen 'n situasie waar daar geen versorging moontlik is nie (vgl. Taking Care 2005:111).

\section{Slot}

Die Nederlandse Mediese Raad meen dat die debat oor eutanasie aan pasiënte met demensie moet voortgaan (Dementia 2002:111). Hierdie studie vorm deel van hierdie breë debat en dit is seker nie onmoontlik dat eutanasie in Suid-Afrika in die toekoms gedebatteer sal word nie.

Dit is duidelik dat eutanasie vir pasiënte met demensie wel in Nederland plaasvind. Die voorlopige gevolgtrekking van hierdie studie is dat eutanasie by pasiënte met gevorderde en vroeë demensie as ' $n$ algemene praktyk baie moeilik vanuit die Skrif verdedig sal kan word. Hoe swaar dit ook al mag wees, bly dit die gelowige se roeping om sy lyding tot die einde soos Christus te verduur, deur daarmee saam te lewe. Vanuit die Christelike etiek mag die uitsondering wel oorweeg word. Dit kan in 'n sondige wêreld gebeur dat 'n gelowige met vroeë demensie in 'n uiters hopelose situasie geplaas word, soos Simson, waar hy moet kies tussen sy eie lewe en 'n beter situasie vir die ander mense. 'Who can say that it is absolutely impossible for the gracious God Himself to help a man in affliction by telling him to take this way out?' (Barth 1964:410). In so 'n geval sal die gelowige homof haarself deeglik voor God as 'n gewetensvraagstuk moet verantwoord dat eutanasie in sy of haar geval inderdaad 'n nodige uitsondering was (Heyns 1986:331). In samehang met laasgenoemde opmerking maak Heyns (1986:335) die volgende uiters betekenisvolle opmerking: 'n werklike sagte, milde, skone en inderdaad goeie dood, is die dood wat in Christus Jesus gesterf word.

\section{Erkenning}

Hierdie artikel word opgedra aan prof. J.M. Vorster. Dit is vir my 'n groot voorreg om my naam in hierdie bundel aan sy naam te mag koppel. Vroeg in my bediening was ek in 'n geloofskrisis oor verskeie kerklike sake. Ek was opsoek na 'n
Gereformeerde teoloog wat my 'n nuwe rigting kon gee en het daarom onder meer die werke van prof. Vorster begin lees. Dit was vir my soos 'n oase in die woestyn. In die bundel Altyd reformeer. Gesprekke oor politiek en godsdiens (1985) wys prof. Vorster daarop dat verandering deel van die nuwe lewe is, terwyl hy waarsku dat die Bybel reg gebruik moet word. Hierdie en ander skrywes het my op 'n nuwe geloofspad geplaas. Ek weet die Gereformeerde kerke is bevoorreg om 'n teoloog met sy akademiese vermoëns te mag hê.

\section{Mededingende belange}

Die outeur verklaar dat sy geen finansiële of persoonlike verbintenis het met enige party wat haar nadelig kon beïnvloed in die skryf van hierdie artikel nie.

\section{Litteratuurverwysings}

Andersen, S. \& Hallamaa, J., 1995, 'Euthanasia: A letter to a nurse on death and dying', in V. Mortensen (ed.), Life and death: Moral implications of biotechnology, pp. 64-70, WCC Publications, Geneva.

Baldwin, R.C., 1995, 'Dementia', in D.J. Atkinson \& D.H. Field (eds.), New dictionary of Christian ethics and pastoral theology, pp. 293-294, InterVarsity, Downers Grove.

Bartelsman, M. \& Jansma, J., 2010, 'Aantal euthanasiegevallen in 2009 sterk gestegen', in Nova Den Haag Vandaag, besigtig 07 Januarie 2010, by http://www.novatv.nl/ page/detail/uitzendingen/7496/Aantal+euthanasiegevallen+in2009+sterk+geste gen\#

Barth, K., 1961, Church dogmatics: The doctrine of Creation, vol. 3, part 4, 2nd edn., transl. A.T. Mackay, T.H.L. Parker, H. Knight, H.A. Kennedy \& J. Marks, T \& T Clark, Edinburgh.

Boer, T.A., 2002, 'Euthanasie: De regel achter de uitzondering' [Eutanasie: Die reël agter die uitsondering], Theologia Reformata 45(2), 126-144, besigtig 15 Desember 2009, by http://www.protestantsetheologischeuniversiteit.nl/ uploadedDocs/medewerkerspagina/boer/Boer-Euthanasie.pdf

Boer, T.A., 2007, '“God” en euthanasie: Een persoonlijk theologisch commentaar' [Eutanasie: 'n Persoonlike teologiese kommentaar], Tijdschrift voor Gezondheidszorg en Ethiek 17(3), 62-66.

Boer, T.A., 2008, Euthanasie: Encyclopedie Protestant.nl., besigtig 15 Desember 2009 by http://www.protestant.nl/themas/gezondheid-en-gezin/opinies/euthanasieenprotestantisme

Boer, T.A., 2009a, epos, 11 Desember 2009, taboer@pthu.nl.

Boer, T.A., 2009b, epos, 15 Desember 2009, taboer@pthu.nl.

Boer, T.A. \& Schroten, E., 1996, 'Life and death seen from a (Dutch) reformed position: A Calvinistic approach to bioethics', in L. Oestnor (ed.), Bioetikk og teologi, Rapport fra Nordisk teologisk nettverk for bioetikks workshop i Stockholm, 27-29 September 1996, pp. 31-51, Nordisk teologisk nettverk for bioetikk, Oslo, viewed 06 December 2009, from http://www.pthu.nl/taboer/

Cameron, N.M. de S., 1995, 'Euthanasia', in D.J. Atkinson \& D.H. Field (eds.), New dictionary of Christian ethics and pastoral theology, pp. 357-359, InterVarsity, Downers Grove.

Charter for compassion, 2009, 'A call to bring the world together', viewed 15 December 2009, from http://charterforcompassion.org/

De Bruyn, P.J., 1993, Die tien gebooie, Varia, Midrand.

De Klerk, W., 1998, Die vreemde God en sy mense, Human \& Rousseau, Pretoria.

Dementia, 2002, Health Council of the Netherlands: Dementia to the Minister of Health, Welfare and Sport, viewed 06 December 2009, from http://www.gr.nl/ sites/default/files/02@04NR.PDF

Douma, J., 1992, De handreiking voor tien het Christelijk geboden leven, (De Tien Geboden, 4-6), Uitgeverij Van den Berg, Kampen.

Douma, J., 1997, Medische ethiek, Kok, Kampen.

Feinberg, J.S. \& Feinberg, P.D., 1993, Ethics for a brave new world, Crosswaybooks, Wheaton.

Gastmans, C. \& De Lepeleire, J., 2009, 'Living to the bitter end? A personalist approach to euthanasia in persons with severe dementia' [Lewe tot die bitter einde, 'n Persoonsmatige benadering tot mense met ernstige demensie], Bioethics 10(1111), 1-9.

Geesink, W., 1931, Gereformeerde ethiek, deel 1, , Kok, Kampen.

Grogan, G.W., 1995, 'Image of God,' in D.J. Atkinson, \& D.H. Field (eds.), New dictionary of Christian ethics and pastoral theology, pp. 476-477, InterVarsity, Downers Grove.

Harris, B., 1995, 'Suicide', in D.J. Atkinson \& D.H. Field (eds.), New dictionary of Christian ethics and pastoral theology, pp. 825-826, InterVarsity, Downers Grove. 
Hertogh, C.M.P.M., De Boer, M.E., Dröes, R.M. \& Eefsting, J.A., 2007a, 'Would we rather lose our life than lose our self? Lessons from the Dutch debate on we rather lose our life than lo oor eutanasie vir pasiënte met demensie], The American Journal of Bioethics $7(4)$ 48-56. http://dx.doi.org/10.1080/15265160701220881

Hertogh, C.M.P.M., De Boer, M.E., Dröes, R.M. \& Eefsting, J.A., 2007b, 'Beyond a Dworkinean view on autonomy and advance directives in dementia: Response to open peer com the Dutch debate on Lessons from the Dutch debate on euthanasia for patients with dementia' [Less uit die Nederlandse debat oor eutanasie vir pasiënte met demensie], The American
Journal of Bioethics 7(4), 4-6. http://dx.doi.org/10.1080/15265160701307696

Heyns, J.A., 1986, Teologiese etiek, deel 2(1): Sosiale etiek, NG Kerkboekhandel, Pretoria.

Heyns, J.A, 1970, Die nuwe mens onderweg: Oor die tien gebooie, Tafelberg, Kaapstad.

Hughes, J.C., 2001, 'Views of the person with dementia', Journal of Medical Ethics 27 , 86-91. http://dx.doi.org/10.1136/jme.27.2.86

Jochemsen, H., 2004, Recent developments in the euthanasia debate in the Netherlands, viewed 22 October 2009, from http://www.lindeboominstituut.nl/ assetmanager.asp?aid $=328$

Joubert, J. \& Bradshaw, D., 2005, 'Population ageing and health challenges in South Africa', in K. Steyn \& J. Fourie (eds.), Chronic diseases of lifestyle unit, Medical Research Council Technical Report, May 2006, pp. 204-219, viewed 01 Decembe 2009, from http://www.mrc.ac.za/chronic/cdl1995-2005.pdf

Nederland, Ministerie van Volksgezondheid, Welzijn en Sport, 2009a, Euthanasie - zorgvuldig van begin tot einde, besigtig 01 Desember 2009, by http://www. rijksoverheid.nl/documenten-en-publicaties/brochures/2010/01/15/euthanasiezorgvuldig-van-begin-tot-einde.html

Nederland, 2009b, Wet toetsing levensbeëindiging op verzoek en hulp bij zelfdoding besigtig 24 Oktober 2009, byhttp://wetten.overheid.nl/BWBR0012410/ geldigheidsdatum_24-10-2009

Regionale Toetsingscommissies Euthanasie, 2005, Jaarverslag 2004, viewed 04 November 2009, from http://www.toetsingscommissieseuthanasie.nl

Regionale Toetsingscommissies Euthanasie, 2006, Jaarverslag 2005, viewed 04 November 2009, from http://www.toetsingscommissieseuthanasie.nl

Regionale Toetsingscommissies Euthanasie, 2007, Jaarverslag 2006, viewed 04 November 2009, from http://www.toetsingscommissieseuthanasie.n

Regionale Toetsingscommissies Euthanasie, 2008, Jaarverslag 2007, viewed 04 November 2009, from http://www.toetsingscommissieseuthanasie.n
Regionale Toetsingscommissies Euthanasie, 2009, Jaarverslag 2008, viewed 04 November 2009, from http://www.toetsingscommissieseuthanasie.nl

Rietjens, J.A.C., Van Der Maas, P.J., Nwuteaka-Philipsen, B.D., Van Delden, J.J.M \& Van Der Heide, A., 2009, 'Two decades of research on euthanasia from the Netherlands: What have we learnt and what questions remain?' [Twee dekades van navorsing oor eutanasie van Nederland: Wat het ons geleer en watter vra bly staan?], Bioethical Inquiry 6, 271-283.http://dx.doi.org/10.1007/s11673-0099172-3

Rurup, M.L., Onwuteaka-Philipsen, B.D., Van Der Heide, A., Van Der Wal, G. \& Van Der Maas, P.J., 2005, "'Physicians" experiences with demented patients with advance euthanasia directives in the Netherlands' ['Geneeshere' se ervaring van pasiënte gevorderde demensie met ' $n$ skriftelike versoek vir eutanasie], Journal of the American Geriatrics Society 53, 1138-1144. http://dx.doi.org/10.1007/s11673009-9172-3

Rurup, M.L., Onwuteaka-Philipsen, B.D., Pasman, H.R., Ribbe, M.W. \& Van Der Wal, G. 2006a, 'Attitudes of physicians, nurses and relatives towards end-of-life decisions concerning nursing home patients with dementia' [Die opinie van geneeshere, verpleegpersoneel en naby familie teenoor eutanasie as oorweging deur persone met demensie in inrigtings vir bejaarde sorg], Patient educ couns 61(3), 372-380. http://dx.doi.org/10.1016/j.pec.2005.04.016

Rurup, M.L., Onwuteaka-Philipsen, B.D., Van Der Heide, A., Van Der Wal, G. \& Deeg, D.J., 2006b, 'Frequency and determinants of advance directives concerning end of-life care in the Netherlands' [Frekwensie en stipulasies in 'n skriftelike versoek deur pasiënte met demensie in Nederland], Social Science and Medicine 62(6), 1552-1563. http://dx.doi.org/10.1016/j.socscimed.2005.08.010

Sorgdrager, W., 2008, 'De arts, de jurist, de ethicus en de dood' [Die geneesheer die juris, die etikus en die dood], Trouw, letter \& geest: 05 Jan., besigtig 15 die juris, die etikus en die dood], Trouw, letter \& geest: 05 Jan., besigtig 15 detail/1634257/2008/01/05/De-arts-de-jurist-de-ethicus-en-de-dood.dhtml

Taking Care, 2005, Ethical caregiving in our aging society: The president's council on bioethics, Washington, D.C., viewed 15 December 2009, from http://bioethics. georgetown.edu/pcbe/reports/taking_care/index.html

Van Wyk, J.H., 1986, Gesindheid en gestalte, N.G. Kerkboekhandel, Pretoria.

Vandrunen, D., 2009, Bioethics and the Christian life: A guide to making difficult decisions, Crossway, Wheaton.

Vilela, L.P. \& Caramelli, P., 2009, Knowledge of the definition of euthanasia: Study with doctors and caregivers of Alzheimer's disease patients, viewed 27 October 2009, from http://www.scielo.br/pdf/ramb/v55n3/v55n3a16.pdf

White, H., 2008, British 'moralist' says dementia patients have a 'duty to die', viewed 24 October 2009, from http://www.catholic.org/international/international story. php?id $=29538$ 